\title{
Result of Fungicides efficacy Evaluation for the Control of Garlic (Allium Sativum L.)Rust (Puccinia Allii Rudolphi) at Holetta, Ethiopia
}

\author{
Habtewold Kifelew $^{1 *}$, Zebenay Dagne ${ }^{2}$, Samuel Tilahun ${ }^{3}$ \\ Holetta Agricultural Research Center, Ethiopia
}

\author{
*Corresponding Author: Habtewold Kifelew, Holetta Agricultural Research Center, Ethiopia
}

\begin{abstract}
The trial was conducted to evaluate fungicide efficacy for the control of Garlic rust at Holeta during 2017 and 2018 cropping season. Four type of fungicide from them three systemic: $-250 \mathrm{gram} / \mathrm{L}$ propiconazole (Tilt 250EC), a mixture of Thiophanate-Methyl $310 \mathrm{gram} / \mathrm{L}$ and Epoxiconazole $187 \mathrm{gram} / \mathrm{L}$ (Rex Due) and Propiconazole; one contact fungicide chlorathalonil 75\% (Rova) and untreated control arranged in RCBD with three replications were used for the study. Rust was found reduce bulb weight, bulb diameter, number of cloves per bulb 55.9\%, 16.33\%, 33.6\% respectively. Yield was found reduced significantly, Rex Duo and Propiconazole were found superior in controlling of rust and give the highest yield $1881 \mathrm{~kg} / \mathrm{ha}$ and $1913 \mathrm{~kg} / \mathrm{ha}$ in 2017 and 2018 respectively. There was up to $106 \%$ yield advantage were obtained from Rex Duo sprayed plot in 2017 and 37.8\% in 2018 cropping season.There was a significant negative correlation observed between Bulb weight, bulb diameter, number of cloves per bulb and yield to that of area under diseases progress curve (AUDPC).Spraying Rex Duo twice at 21-days interval starting from the onset of the disease insured a gain of 46818.125 Ethiopian Birr (ETB) per hectare additional net benefit and maximum marginal rate of return $1440.6 \%$.
\end{abstract}

Keywords: Garlic, Fungicide, Rust

\section{INTRODUCTION}

Ethiopian Diverse agro-ecology enables the country to produce both cool and warm season vegetable. Garlic (Allium sativum L.) is a cool season vegetable usually produced in the highlands of Ethiopia. It is the second most widely produced and used Allium next to onion (Rochecouste, 1984). Garlic is produced in Ethiopia by 2,255,598 small scale farmer's field on 19412.49hactares of land, from which 178221.893 tones have been produced in 2018 with the national average productivity 9.181 tons per hectares (CSA, 2018).Its production and productivities increased in the last two decade, however starting from 2014 production and productivity of garlic decreased mainly due to white rot and rust epidemics.

Garlic rust caused by (Pucinnia alli) is the major constraint in garlic production and cause up to $58.75 \%$ yield loss in Ethiopia (Worku et.al., 2016),yield loss up to $51 \%$ due to rust infection in California and Serious outbreak could reduce bulb weight from 25-60\% with deterioration in quality(Koike et. al.,2001). Rust is primarily a disease of garlic, although onion, leeks, shallots, and wild species of Allium are hosts.

There is a few work has been done to manage the pathogen. Spraying of Nativo SC 300 (Trifloxystrobin 100g/l + Tebuconazole 200g/l) three times at 14-days interval control the disease at Bale (Yonas, 2017); increasing intra-row spacing from 10 to $20 \mathrm{~cm}$ decreased disease incidence (Worku and Azene, 2015), since there is no resistance variety available in the country and Ethiopia is known hot spot for many rust pathogen and races, controlling of the pathogen using chemical is mandatory, however, there is no a single fungicide registered for the controlling of garlic rust but there is many fungicide for the control of rust in wheat and flower have been registered and available in the market. So the present study is to verify the already registered fungicide for the control of garlic rust 


\section{MATERIALS AND METHOD}

The study was conducted at Holetta Agricultural Research center for two years 2017 \& 2018, which is located $9^{\circ} 00^{\prime} \mathrm{N}$ and $38^{\circ} 30^{\prime} \mathrm{E}$, Altitude 2400 meter above sea level, Rainfall $1144 \mathrm{~mm}$, and annual minimum and maximum Temperature $6^{\circ} \mathrm{C}$ and $22^{\circ} \mathrm{C}$ respectively.

A uniform size cloves of garlic variety "Tsedey" was used, which is improved and widely grown variety, four type of fungicide from them three systemic:-250 gram/L propiconazole (Tilt 250EC), a mixture of Thiophanate-Methyl 310 gram/L and Epoxiconazole $187 \mathrm{gram} / \mathrm{L}$ (Rex Due) and Propiconazole; one contact fungicide chlorathalonil 75\% (Rova) and untreated control arranged in RCBD with three replications were used. Each plot was consists of five double rows of two meter length with three meter wide. The cloves were planted on both side of the ridge by $10 \mathrm{~cm}$ distance between plants and $20 \mathrm{~cm}$ between rows and $40 \mathrm{~cm}$ between double rows. The fungicide sprays starting from the onset of the diseases using the rate of the company recommendation on the label. We estimated disease severity using 0 to 5 scale ( 0 signified that $0 \%$ of the leaf surface was covered with pustules, 1 meant $1 \%$ to $10 \%$ was covered, 2 meant $11 \%$ to $25 \%, 3$ meant $26 \%$ to $50 \%, 4$ meant $51 \%$ to $75 \%$, and 5 meant $76 \%$ to $100 \%$ ). We evaluated ten plants per plot and derived a mean value for each plot. We determined plot yields by harvesting garlic from a 2 meter length in the middle three double rows of each plot. We trimmed harvested bulbs according to standard commercial practice and weighed them, number of cloves per bulb, bulb diameter, and bulb weight also collected from each plot. Data subjected to analysis using (SAS, 10 versions)

\section{RESULT AND DISCUSSIONS}

The diseases onset is observed most frequently under conditions of high humidity and low rainfall which is mid-September to early October at Holetta. During diseases development a Small, reddish to dull orange oval-shaped pustules were developed on leaf blades. Subsequently Reddish airborne urediospores were produced within the lesions. Later in the growing season, the lesions may appear dark because black teliospores develop within the pustules. The severity of the diseases reaches maximum the leaves to turn yellow and collapse prematurely. In the fungicide trials, Propiconazoel and Rex Duo consistently provided the best control of rust and gives highest garlic yields followed by Tilt 250E whereas, Rova was found list in controlling of rust diseases.

Table1. Yield and yield components of garlic and the corresponding relative yield advantage due to garlic rust under different fungicide

\begin{tabular}{|c|c|c|c|c|c|c|c|c|c|}
\hline \multirow[t]{2}{*}{ Treatment } & \multirow{2}{*}{$\begin{array}{c}\text { Bulb } \\
\text { weight } \\
\text { (gram) }\end{array}$} & \multirow{2}{*}{$\begin{array}{c}\text { Bulb } \\
\text { diameter } \\
(\mathrm{cm})\end{array}$} & \multirow{2}{*}{$\begin{array}{l}\text { number } \\
\text { of cloves } \\
\text { per bulb }\end{array}$} & \multirow{2}{*}{\begin{tabular}{|c|} 
Clove \\
weight
\end{tabular}} & \multirow[t]{2}{*}{ AUDPC } & 2018 & 2017 & 2018 & 2017 \\
\hline & & & & & & \multicolumn{2}{|c|}{$\begin{array}{l}\text { Yield kilogram } \\
\text { per hectare }\end{array}$} & \multicolumn{2}{|c|}{$\begin{array}{c}\text { Relative yield } \\
\text { advantage over the } \\
\text { unsprayed check }(\%)\end{array}$} \\
\hline $\begin{array}{l}\text { Unsprayed } \\
\text { control }\end{array}$ & $6.933^{\mathrm{B}}$ & $2.65^{\mathrm{B}}$ & $5.133^{\mathrm{B}}$ & 6.9 & $488.33^{\mathrm{A}}$ & $913.1^{\mathrm{B}}$ & $1387.9^{\mathrm{B}}$ & 0 & 0 \\
\hline Tilt 250EC & $10.867^{\mathrm{AB}}$ & $3.1733^{A}$ & $7.067^{\mathrm{AB}}$ & 9.267 & $40^{C}$ & $1560.6^{\mathrm{AB}}$ & $1656.6^{\mathrm{AB}}$ & 70.91 & 19.36 \\
\hline Rova & $9.733^{\mathrm{AB}}$ & $2.82^{\mathrm{AB}}$ & $6.277^{\mathrm{AB}}$ & 8.00 & $165^{\mathrm{B}}$ & $1643.4^{\mathrm{AB}}$ & $1320.2^{\mathrm{B}}$ & 79.98 & -4.88 \\
\hline Rex Duo & $11.933^{\mathrm{A}}$ & $3.11^{\mathrm{A}}$ & $7.267^{\mathrm{AB}}$ & 8.8 & $13.33^{C}$ & $1881.8^{\mathrm{A}}$ & $1455.6^{\mathrm{B}}$ & 106.08 & 37.85 \\
\hline Propiconazole & $12.40^{\mathrm{A}}$ & $3.05^{\mathrm{A}}$ & $7.733^{\mathrm{A}}$ & 8.9 & $26.67^{C}$ & $1451.5^{\mathrm{AB}}$ & $1913.1^{\mathrm{A}}$ & 58.96 & 4.88 \\
\hline LSD & 4.32 & 0.373 & 0.492 & NS & 68.881 & 834.24 & 422.09 & & \\
\hline $\mathrm{CV}$ & 22.1 & 6.69 & 10.29 & & 24.9 & 29.7 & 14.49 & & \\
\hline
\end{tabular}

Bulb weights were found highly affected by rust and there were a significant difference among different fungicide spray and unsprayed plot. Since rust is highly affected the leaf and steam during the diseases progresses those specks expand into oblong lesions then the tissue covered with the lesion ruptures results the leaves to collapse. Even with low severity can reduce the photosynthesis area as well as the economic yield bulb weight

The highest bulb weight loss from the unsprayed plots to that of Propiconazole sprayed plot was $55.9 \%$. According to Ram D. Timila et.al. (2005), serious outbreak could reduce bulb weight from 25$60 \%$ with deterioration in quality.

Bulb diameter was found significantly affected by rust. From the trial there is a significant difference among fungicide spray and unsprayed plot. The highest bulb diameter $(3.1733 \mathrm{~cm})$ was recorded on 
bulbs from Tilt 250EC sprayed plot while the smallest $(2.65 \mathrm{~cm})$ was from unsprayed plots. The highest relative reduction $(16.33 \%)$ in bulb diameter was obtained from the unsprayed plots

There was a significant difference in the number of cloves per bulb among the different fungicides spray and unsprayed field. Loss in cloves number per bulb is $33.6 \%$ in unsprayed control compare with Propiconazole sprayed plot. According to Mirzaei et.al. (2007) there was a significant different in number of cloves per bulb

Men cloves weight was found not significant different among the treatments however, a slight increase in clove weight is observed in fungicide sprayed plot than the control

Yield were found highly affected by rust, there was a significant difference among the treatments in both years on yield of garlic. Rex Duo and Propiconazole were found superior in controlling of rust and give the highest yield $1881 \mathrm{~kg} / \mathrm{ha}$ and $1913 \mathrm{~kg} / \mathrm{ha}$ in 2017 and 2018 respectively. There was up to 106\% yield advantage were obtained from Rex Duo sprayed plot in 2017 and 37.8\% in 2018 cropping season

Over all the yield and yield related parameters shows highly affected by rust since rust affected leaves turn yellow, wilt and dry up, and die prematurely. Garlic bulbs on such plants can be significantly reduced in size and quality, with affected bulbs often lacking their protective dry outer skins thereby leaving them prone to shattering during harvest.

Table2. Partial budget analysis of fungicide application on garlic for the control of rust

\begin{tabular}{|l|l|l|l|l|l|}
\hline Parameters & Fungicides & \multicolumn{4}{l|}{} \\
\hline Treatment & Unsprayed & Tilt 250EC & Rova & Rex Duo & Propiconazole \\
\hline Gross average yield (q/ha) & 913 & 1560 & 1643 & 1881 & 1451 \\
\hline Adjusted yield (q/ha) 0.9 & 821.7 & 1404 & 1478.7 & 1692.9 & 1305.9 \\
\hline Price (1kg=57.5EBirr) & 57.5 & 57.5 & 57.5 & 57.5 & 57.5 \\
\hline Sale revenue & 47250.625 & 80730 & 85025.25 & 97318.75 & 75089.25 \\
\hline Marginal cost & 0 & 3250 & 2850 & 3250 & 3250 \\
\hline Net benefit (ETB) & 47250.625 & 77480 & 82175.25 & 94068.75 & 71839.25 \\
\hline Marginal benefit & 0.00 & 30229.375 & 34924.625 & 46818.125 & 24588.625 \\
\hline Marginal rate of return (MRR) & 0.00 & 930.13 & 1225.4 & 1440.6 & 756.6 \\
\hline
\end{tabular}

The result of partial budget analysis of Rex Duo application on garlic field proved an increase in net benefit due to fungicide application which resulted higher total bulb yield. Spraying Rex Duotwice at 21-days interval starting from the onset of the disease insured a gain of 46818.125 Ethiopian Birr (ETB) per hectare additional net benefit and maximum marginal rate of return 1440.6\%.

Table3. Result of Correlation between parameters

\begin{tabular}{|c|c|c|c|c|c|c|}
\hline & & $\begin{array}{l}\text { Bulb } \\
\text { weight }\end{array}$ & $\begin{array}{l}\text { Bulb } \\
\text { diameter }\end{array}$ & $\begin{array}{l}\text { Number of } \\
\text { cloves per bulb }\end{array}$ & $\begin{array}{l}\text { Yield } \\
\text { kg/ha }\end{array}$ & AUDPC \\
\hline Bulb weight & Pearson Correlation & 1 & .878 & $.992^{* * *}$ & .783 & $-.967^{* * *}$ \\
\hline & Sig. (2-tailed) & & .050 & .001 & .117 & .007 \\
\hline & $\mathrm{N}$ & 5 & 5 & 5 & 5 & 5 \\
\hline Bulb diameter & Pearson Correlation & .878 & 1 & $.897^{*}$ & .724 & $-.923^{*}$ \\
\hline & Sig. (2-tailed) & .050 & & .039 & .167 & .025 \\
\hline & $\mathrm{N}$ & 5 & 5 & 5 & 5 & 5 \\
\hline Number of cloves & Pearson Correlation & $.992^{* *}$ & $.897^{*}$ & 1 & .715 & $-.957^{*}$ \\
\hline per bulb & Sig. (2-tailed) & .001 & .039 & & .175 & .011 \\
\hline & $\mathrm{N}$ & 5 & 5 & 5 & 5 & 5 \\
\hline Yield kg/ha & Pearson Correlation & .783 & .724 & .715 & 1 & -.866 \\
\hline & Sig. (2-tailed) & .117 & .167 & .175 & & .058 \\
\hline & $\mathrm{N}$ & 5 & 5 & 5 & 5 & 5 \\
\hline AUDPC & Pearson Correlation & $-.967^{* *}$ & $-.923^{*}$ & $-.957^{*}$ & -.866 & 1 \\
\hline & Sig. (2-tailed) & .007 & .025 & .011 & .058 & \\
\hline & $\mathrm{N}$ & 5 & 5 & 5 & 5 & 5 \\
\hline
\end{tabular}

**correlation is significant at the 0.01 level (2-tailed)

*correlation is significant at the 0.05 level (2-tailed) 
Bulb weight, bulb diameter, number of cloves per bulb and yield were found a signification negative correlation with area under diseases progress curve (AUDPC).

\section{CONCLUSION}

Rust was found reduce bulb weight, bulb diameter, number of cloves per bulb 55.9\%, 16.33\%, $33.6 \%$ respectively. Yield was found reduced significantly, Rex Duo and Propiconazole were found superior in controlling of rust and give the highest yield $1881 \mathrm{~kg} / \mathrm{ha}$ and $1913 \mathrm{~kg} / \mathrm{ha}$ in 2017 and 2018 respectively. There was up to $106 \%$ yield advantage were obtained from Rex Duo sprayed plot in 2017 and 37.8\% in 2018 cropping season. Maximum Marginal rate of return 1440.6\% were recorded for Rex Duo fungicide sprayed plot whereas the list was Propiconazole $756.6 \%$. There was a significant negative correlation observed between Bulb weight, bulb diameter, number of cloves per bulb and yield to that of area under diseases progress curve (AUDPC). Spraying Rex Duo twice at 21days interval starting from the onset of the disease insured a gain of 46818.125 Ethiopian Birr (ETB) per hectare additional net benefit and maximum marginal rate of return 1440.6\%.

\section{REFERENCES}

[1] Central Statistical Agency (CSA). 2018. The Federal Democratic Republic of Ethiopia Agricultural Sample Survey, Volume I Reporton Area and Production of Major Crops, Addis Ababa, Ethiopia

[2] Koike ST, Smith RF, Davis RM, Nunez JJ and Voss RE. 2001. Characterization and control of garlic rust in California. Plant Dis. 85:585-591.

[3] Mengesha W and Tesfaye A. 2015. Effect of Spacing in Incidence and Severity of Garlic Rust (Puccinia Allii (Rudolphi.) and Bulb Yield and Related Traits of Garlic at Eastern Ethiopia. J Plant Pathol Microbiol 6:314. doi:10.4172/2157-7471.1000314

[4] Rochecouste J.F.G. 1984. Chemical control of garlic rust. Australasian Plant Pathology 13: 47-48.

[5] Ram D Timila, Sharada Joshi, Gyanu Manandhar and Sarala Sharma. 2005. Occurrence of Garlic Rust in Mid Hill of Nepal Nepal Agric. Res. J. Vol. 6, 2005

[6] Worku M., Azene T., and Mashilla D., 2016. Evaluation of fungicides on the control of garlic rust (puccinia alli) in Eastern Ethiopia. International Journal of Emerging Technology and Advanced Engineering ISSN 2250- 2459 ISO9001:2008 Certified Journal, Volume 6, Issue 1.

[7] Yonas Worku Mulat. 2017. Determination of Optimum Nativo SC 300 (Trifloxystrobin 100g/l + Tebuconazole 200g/l) Spray Frequency for Control of Rust (Puccinia allii Rudolphi) on Garlic in Bale Highlands, South Eastern Ethiopia. American Journal of Agriculture and Forestry. Vol. 5, No. 2, 2017, pp. 16-19. doi: 10.11648/j.ajaf.20170502.11

Citation: Habtewold Kifelew, et.al. "Result of Fungicides efficacy Evaluation for the Control of Garlic (Allium Sativum L.)Rust (Puccinia Allii Rudolphi) at Holetta, Ethiopia" International Journal of Research Studies in Agricultural Sciences (IJRSAS), 2019; 5(5), pp. 1-4, http://dx.doi.org/10.20431/2454-6224.0505001

Copyright: () 2019 Authors. This is an open-access article distributed under the terms of the Creative Commons Attribution License, which permits unrestricted use, distribution, and reproduction in any medium, provided the original author and source are credited. 